programme" and on the need for redeploying the Ispra Research Centre more and more for non-nuclear work. Yet, Euratom apart, great progress has been made to the extent that the idea of combined scientific policies among the Six, inconceivable a few months ago, seems to be gaining ground. This ambitious objective will not be reached immediately. For the moment, Professor Aigrain and his colleagues have at least managed the difficult job of classifying in order of priority a list of some 47 projects. This initial list had been drawn up at the beginning of 1969 as a result of reports received from seven specialist subgroups. These subgroups, whose members and methods were the subject of a good deal of discussion (especially by the Belgians who would have preferred the study to be global rather than sector by sector), are probably going to be dissolved. The only one to remain will be the group specializing in the problems of data processing, which is generally recognized to have done excellent work. Its favourite project, the plan for a large European computer, is moreover going well. Since the beginning of the year, secret discussions had been held between emissaries from Brussels and ICL, which had already built into its programme the construction of a machine of comparable size, the 1908A. The Six's experts considered it vital to cooperate with the British firm, whose superiority over its continental rivals is unquestionable, if the European computer project was indeed to come to fruition. And again the size of the market made it absurd to make two attempts to meet the American challenge at the same time. The announcement by ICL a few weeks ago that the 1908A should be abandoned really only represents another stage in a long series of diplomatic manoeuvres. It was certainly not by chance that EEC representatives had been in London for two days when ICL's statement was issued. At all events, one thing is certain: in Brussels it is believed that the chances of a large machine being developed collectively by the Six and Britain have increased during the last few weeks.

ICL, moreover, announced in a second statement that the 1908A had not, strictly speaking, been abandoned but replaced by the enigmatic Project 52 . According to information received by the EEC this is, in fact, a counter-project to the proposals of the Aigrain group which has in effect been known about in Brussels for some time. There is no feeling of suspense among the initiated. Yet it should be made clear that the decision to be taken by the Six will only concern, for the time being, the official appraisal of the project (its technical feasibility, the extent and nature of the market and so on). Building the machine properly is quite another matter. ...

The European ventures are not, a priori, destined inevitably to succeed. But the will to give them a serious try is nonetheless a fairly new sign of realism in Paris. It is worthy of note that while France envisages cooperation with present-or future-members of the EEC, it is having to restrict the national effort in the field of computers. The Plan Calcul, the anti-IBM war machine of former ministers, had ambitions too lofty for its restricted means to be very convincing. Now the capital given over to the plan is also decreasing, from 174 to 168 million francs. On the other hand, so far as software is concerned, the government, which was firmly opposed to American participation (by Leasco) in the leading French company SEMA, does not seem to disapprove of the discussions currently being held between it and Philips.

The intensified European "overture", the touch on the brake for programmes which are at the heart of orthodox Gaullism such as the Plan Calcul, the graphite-plus-gas process, space exploration-all this is not simply the result of a period of economic difficulty. More importantly, the aims of a scientific policy which has been operating for 10 years are being called into question. This shows itself in the change of title of the Minister for Science (now Minister for Industrial Development and Scientific Research, and conferred on a former Finance Minister), and in the formation of an Institute for Industrial Development (IDI) which will be run like a private firm and which will have a function similar to that of the IRC in Britain.

The grand ideas behind this new strategy aimed at profitability or, more generally, efficiency are not new. They have been tried elsewhere and even aired in France many a time. Will they be applied with energy and foresight by the government in Paris? Will the sacrifices that this policy inevitably implies, particularly for fundamental research, pay off? On the protest day on October 10, the director of one laboratory said: "With this policy, there is a danger of throwing the baby away with the bath water". His assistant corrected him: "The real danger is of throwing the baby away without the bath water".

\title{
Recipe for Change at Universities
}

SwEEPING changes in the British system of higher education have been proposed by the House of Commons Select Committee on Education and Science in its report on student relations which was published last week (HMSO, $17 s 6 d$ ). Its main proposals are for the setting up of a Higher Education Commission to be responsible for all institutions of higher education, the abolition of the distinction between universities and other institutions and the representation of students on the governing bodies of universities and colleges. The report has for the most part been warmly received, although there has been some surprise that its recommendations go much further than its title suggests.

The committee, which consisted of thirteen backbench Labour and Conservative Members of Parliament, began collecting evidence last December. It visited sixteen universities (including four in Scotland), five colleges of art, three colleges of education and four other colleges. Among those who gave evidence to 
the committee were Mr Edward Short, Secretary of State for Education and Science, Sir William Alexander, secretary of the Association of Education Committees, and representatives of the National Union of Students, the Committee of Vice-Chancellors, the Association of University Teachers and the Association of Teachers in Technical Institutions. The committec says that it has found a variety of reasons for dissatisfaction among students, but that it "cannot claim that we can confidently diagnose the causes of student unrest, but at least we have been able to expose a few misconceptions". The report also emphasizes that "it would be a mistake not to consider criticism seriously, and facile to assume that student unrest is merely temporary".

The report says that there is "little evidence to suggest that unrest in British universities and colleges owes much to international inspiration", but that "student unrest reflects not only the problems of students in higher education but also those facing all young people in modern society". The committee says that the rapid expansion of higher education has caused a deterioration in communications between staff and students, that there is dissatisfaction with the obvious inequalities between universities and other institutions of higher education and that students are unable to influence decisions. On the last point the report comes down firmly in favour of student participation, especially on the council and senate in universities and on the governing body and academic board in the local authority colleges. Moreover, full student participation in the management of welfare services "is not only desirable but necessary". The committee says, however, that the student members of committees should be representatives and not mandated delegates.

The National Union of Students claims that it has been advocating many of the recommendations for a long time. The establishment of a higher education commission was indeed suggested by the NUS in its evidence to the Robbins Committee. The commission is evidently regarded by the select committee as the central body through which most of its other proposals would be implemented. Its powers would extend to all institutions of higher education, including universities, colleges of education and polytechnics, and its main purpose would be to collect and disseminate information and to guide and coordinate the activities of the higher education institutions. Thus the committee suggests that the commission should collect information on student involvement in making academic decisions; approve the constitutions of student unions; approve disciplinary procedures at individual institutions and collect information and advise on disciplinary matters; promote research on teaching methods and examinations; and "provide a national forum for discussion on matters of common interest to institutions of higher education".

The report criticizes the University Grants Committee for taking a restricted view of its functions and suggests that many of the functions proposed for the Higher Education Commission should have been carried out by the UGC. "The UGC has, for example, given little attention to the social effect of various forms of expansion. It seems to have been little concerned with haphazard proliferation of courses. It has not investigated the significance of staff/student ratios. And, although it has recently done constructive and effective work on student progress, it has shown little positive interest in student relations."

The report constantly criticizes the separation of higher education into university and non-university sectors and says that "in the context of student relations, the binary system is unfortunate" because it "produces a feeling of first and second class citizenship in higher education". For this reason, the committee urges that the government should consider how all institutions of higher education can be financed in the same way, but it is not especially helpful about the placing of financial responsibility. Instead, the committee says that "the commission could assume all the functions of the University Grants Committee and provision could be made within its structure for a committee constituted in the same way as the University Grants Committee and continuing its present functions, until uniform provision is made for the financing of all the institutions of higher education".

The report also calls for a more realistic appraisal and review of courses, welcoming "the very real and serious interest of students in what they are being taught", and urging that more attention should be paid to the introduction of students to basic questions and common problems. "Students of science and technology should have greater opportunity to take courses designed to help them to appreciate the impact of science on society", for example. On accommodetion, the committee recommends an extension of the system of privately financed loans for building residential accommodation and a national review of residential accommodation so that guidance can be given for the planning of polytechnics.

This report has been widely praised, but some of the most fundamental criticisms have ironically come from a member of the committee, Mr Ronald Bell, Conservative MP for South Buckinghamshire, who said last week that the Higher Education Commission "could not fail to become a controlling body" and that it would also "become an instrument for the campaigns of militant student bodies". Mr Bell is also concerned that student representation on governing bodies "will merely give status to militant elements, for it will often be the wrong sort of students who find their way on to the representative bodies". Mr Bell scems to have found that his views were not often shared by other members of the committee. Sir Derman Christopherson, chairman of the Committee of Vice-Chancellors, has also expressed reservations about the report. saying that a commission might be led to impose too much uniformity on higher education. However, he said that he would "not disagree with" a proposal for the UGC type of machinery for the public sector.

The NUS has welcomed the report "as a constructive contribution to the problem of student relations" and claims that it endorses its own view of the "administrative chaos of higher education and the inequalitics produced by the binary system". The NUS is not, however, so happy that the commission should approve the constitution of students' unions, and it is also alarmed that the proposed commission should regulate disciplinary matters in case this should tempt it to keep a kind of black list.

The select committec became defunct when it made its report, and its final recommendation was that a new select committec should be set up as soon as possible, so that the inquiry which it has already started into the provision of teacher training can be completed. 